\title{
Reduced Effectiveness of Contraceptive Implants for Women Taking the Antiretroviral Efavirenz (EFV): Still Good Enough and for How Long?
}

James D Shelton ${ }^{a}$

\begin{abstract}
EFV clearly reduces effectiveness of implants. However, the reduced effectiveness still appears better compared with short-acting methods overall, at least for the initial period of implant use, and may be acceptable to many women. We need better data on effectiveness, especially over the long term and on whether ENG implants (Implanon) might be more effective than LNG implants (Jadelle). Communicating the risk of pregnancy to clients under these circumstances is very challenging. In the longer term, providing an alternative to EFV, such as dolutegravir, might solve this problem.
\end{abstract}

\section{WHY REDUCED EFFECTIVENESS OF IMPLANTS IS AN IMPORTANT PROBLEM}

$\mathrm{T}$ he antiretroviral (ARV) efavirenz (EFV) is now recommended for first-line antiretroviral therapy (ART) by the World Health Organization (WHO). ${ }^{1}$ And since WHO now recommends ART for all people living with $\mathrm{HIV}^{2}$ that makes virtually all the some 13 million women in sub-Saharan Africa living with $\mathrm{HIV}^{3}$ candidates for extended EFV use.

At the same time, contraceptive implants have many attractive features ${ }^{4}$ and are the fastest growing method of contraception in sub-Saharan Africa-taking a markedly increasing share of the contraceptive method mix. The reduced effectiveness of implants due to an interaction with EFV could result in many unwanted pregnancies among vulnerable women and undermine confidence in an outstanding contraceptive method.

\section{HOW DOES EFV DECREASE EFFECTIVENESS OF IMPLANTS?}

By reducing contraceptive hormone levels. The very high contraceptive efficacy of implants comes from consistent release of low but highly effective levels of progestin in the blood. However, EFV speeds up the normal degradation of contraceptive progestins including those in implants (though not that of the injectable DMPA), lowering the progestin blood levels by roughly half..$^{5-9}$ Because blood levels are already quite low, such

aGlobal Health: Science and Practice, Editor-in-Chief, Washington, DC, USA. Correspondence to James D Shelton (jshelton@ghspjournal.org). a large reduction can lead to levels below the threshold at which the implant's typically very high effectiveness is assured. Moreover, the progestin blood levels with implants are highest very soon after insertion and normally decline over the multiple years of an implant's use. Thus, with continued EFV (and implant) use, these still lower progestin levels are expected to increase the risk of pregnancy over time.

\section{HOW MUCH DOES EFV REDUCE EFFECTIVENESS OF IMPLANTS?}

Implants are normally extremely effective with a failure rate of less that $1 \%$ per year. ${ }^{10}$ Although the available studies on effectiveness of implants among women on EFV are limited, as shown in the Table, pregnancy rates for women on EFV are well above 1\%. (Note data from the single Patel study ${ }^{11}$ are shown separately for the 2 types of implants.) The one exception is the small study of 25 women from Brazil, ${ }^{14}$ which found no pregnancies. Otherwise, the rates range from about $6 \%$ to $15 \%$.

\section{MIGHT ENG IMPLANTS BE MORE EFFECTIVE THAN LNG IMPLANTS?}

The 2 leading implants are the single-rod Implanon, which releases the progestin etonogestrel (ENG), and the 2-rod Jadelle, which releases levonorgestrel (LNG). The primary mechanism for ENG and LNG implants is suppressing ovarian activity. Both are very highly effective, but the ENG implant is more effective than the LNG implant in suppressing ovarian activity. ${ }^{16,17}$ 
TABLE. Pregnancy Rates in Studies of Contraceptive Implants and the Antiretroviral Efavirenz

\begin{tabular}{|c|c|c|c|c|c|}
\hline $\begin{array}{l}\text { Implant Type } \\
\text { and Study }\end{array}$ & Methodology & $\begin{array}{l}\text { No. of } \\
\text { Women }\end{array}$ & $\begin{array}{c}\text { No. of } \\
\text { Pregnancies }\end{array}$ & $\begin{array}{c}\text { Pregnancy Rate } \\
(95 \% \mathrm{CI})\end{array}$ & $\begin{array}{l}\text { Period of } \\
\text { Use }\end{array}$ \\
\hline \multicolumn{6}{|l|}{ LNG } \\
\hline Patel $^{11}$ & Retrospective electronic database & $191^{\mathrm{a}}$ & 6 & $7.1(1.5,12.6)$ & Unknown \\
\hline Perry $^{12}$ & Retrospective chart review & 121 & 15 & $10^{a}$ & 16.4 months \\
\hline Scarsi $i^{13}$ & Prospective clinical & 20 & 3 & 15 & 48 weeks \\
\hline \multicolumn{6}{|l|}{ ENG } \\
\hline Patel $^{11}$ & Retrospective electronic database & $641^{\mathrm{a}}$ & 15 & $5.5(2.5,8.4)$ & Unknown \\
\hline Kreitchmann $^{14}$ & Prospective clinical & $25^{b}$ & 0 & 0 & 3 years \\
\hline \multicolumn{6}{|l|}{ Unknown } \\
\hline Pyra ${ }^{15}$ & Secondary analysis of prospective study & $9^{a}$ & 1 & 6 & Unknown \\
\hline
\end{tabular}

For women taking EFV, the results presented in the Table suggest better pregnancy prevention for the ENG implant than for the LNG implant, with failure rates from $0 \%$ to $6 \%$ versus $7 \%$ to $15 \%$, respectively. On the other hand, in the large retrospective study by Patel $^{11}$ based on electronic records of clinic visits, while the failure rate was a bit better for those using the ENG implant (5.5\%) than the LNG implant $(7.1 \%)$, the rates are fairly similar. However, even in that study, the numbers of pregnancies, particularly for the LNG implant, were very few and confidence intervals very large, so this study result is still compatible with a substantial difference in effectiveness.

\section{WHAT ABOUT THE EXPECTED INCREASE IN PREGNANCY RATES IN THE LATER YEARS OF IMPLANT USE WITH EFV?}

Unfortunately we are largely in the dark, except that the pregnancy rates are bound to increase with longer duration of use. The blood level data suggest gradually declining levels of progestin over time, but that provides little insight. Only the small Brazil study ${ }^{14}$ has data for as many as 3 years. In the Patel study, ${ }^{11}$ information on duration was not available in the electronic database. But use of implants most probably tended to be early use, since implant use has only been rapidly scaling-up in recent years.
FOR WOMEN TAKING EFV, HOW DOES THE REDUCED EFFECTIVENESS WITH IMPLANTS COMPARE WITH OTHER CONTRACEPTIVE METHODS?

For the initial time period at least, still generally better overall than the short-acting methods of oral contraceptives and injectables. The Patel study also assessed failure rates with other contraceptive methods for women taking EFV and found considerably higher failure rates with women using oral contraceptives and injectables compared with implants, though of course lower failure rates with IUDs and permanent methods. ${ }^{11}$ That higher risk with the short-acting methods was probably largely due to inconsistent use of pills and injectables. However, it is possible some of the women who reported use of a short-acting method, as recorded in the electronic database, may then have discontinued to become pregnant intentionally. But that seems unlikely to affect the overall finding that pregnancy rates for women taking EFV were better with implants than with injectables or pills.

\section{WHAT DOES THIS EVIDENCE IMPLY FOR RECOMMENDATIONS ON USE OF IMPLANTS FOR WOMEN ON EFV?}

Use of implants for women taking any ARV continues to fall under WHO Category 2, which is
For women taking EFV, the ENG implant might be more effective than the LNG implant.

The antiretroviral efavirenz speeds up the degradation of progestins found in contraceptive implants.

Risk of pregnancy with continued EFV and implant use is expected to increase over time.

Pregnancy rates in women using EFV and implants generally range from $6 \%$ to $15 \%$. 
the "generally use" category. ${ }^{18}$ And the current evidence supports that position. As Patel recommends, "... all HIV-positive women should be offered all currently available contraceptive methods, and counseled about failure rates when used with efavirenz-based ART."11

\section{The reduced contraceptive effectiveness \\ CONVEYING THIS EVIDENCE ON EFFECTIVENESS TO CLIENTS IS VERY CHALLENGING} when taking EFV and implants is still generally better overall than effectiveness of short-acting methods.

The body of knowledge on the advantages and disadvantages of contraceptive methods is exceedingly complex, and realistically only the most important information can be conveyed to clients. Effectiveness is clearly important, but it is already difficult to convey. And our limited and imprecise evidence on effectiveness of implants for women on EFV, especially over the long term, makes communicating it even more complex. Moreover, we don't know if the ENG implant might be a better choice over the LNG implant. Personally, if I were such a client who wanted an implant, if given the choice, I would likely select an ENG implant, since the effectiveness is unlikely to be worse and might be better. But of course other factors weigh in on any individual's choice. Clearly we need more evidence.

\section{Use of implants for NEW ARVS A POSSIBLE LONGER-TERM women taking SOLUTION}

any ARV continues to fall under WHO Category 2"generally use."
One way out of this dilemma would be replacing EFV with another ARV that did not significantly reduce progestin blood levels. For example dolutegravir-an integrase inhibitor-has a number of advantages over EFV including apparently avoiding the way EFV reduces progestin blood levels. ${ }^{19-21}$ US guidelines already recommend such integrase inhibitors for first-line therapy, and EFV has been demoted to an alternative regimen. ${ }^{22}$ Dolutegravir is not widely available in developing countries as yet, though processes are in place hopefully to make it so in the coming years. Meanwhile, if and when it becomes available, preference for providing it to women choosing and using implants makes considerable sense.

Competing Interests: None declared.

\section{REFERENCES}

1. World Health Organization (WHO). Consolidated guidelines on the use of antiretroviral drugs for treating and preventing HIV infection: recommendations for a public health approach. Geneva: WHO; 2013. Available from: http://www.who.int/hiv/ pub/guidelines/arv2013/en/
2. World Health Organization (WHO). Guideline on when to start antiretroviral therapy and on pre-exposure prophylaxis for HIV. Geneva: WHO; 2015. Available from: http://www.who.int/hiv/ pub/guidelines/earlyrelease-arv/en/

3. UNAIDS. The gap report. Geneva: UNAIDS; 2014. Available from: http://www.unaids.org/en/resources/campaigns/2014/ 2014gapreport/gapreport

4. Jacobstein R, Stanley H. Contraceptive implants: providing better choice to meet growing family planning demand. Glob Health Sci Pract. 2013;1(1):11-17. CrossRef. Medline

5. Scarsi K, Lamorde M, Darin K, Penchala SD, Else L, Nakalema S, et al. Efavirenz- but not nevirapine-based antiretroviral therapy decrease exposure to the levonorgestrel released from a sub-dermal contraceptive implant. J Int AIDS Soc. 2014;17(4 Suppl 3):19484. CrossRef. Medline

6. Vieira CS, Bahamondes MV, de Souza RM, Brito MB, Rocha Prandini TR, Amaral E, et al. Effect of antiretroviral therapy including lopinavir/ritonavir or efavirenz on etonogestrel-releasing implant pharmacokinetics in HIV-positive women. J Acquir Immune Defic Syndr. 2014;66(4):378-385. CrossRef. Medline

7. Sevinsky H, Eley T, Persson S, Garner D, Yones C, Nettles R, et al. The effect of efavirenz on the pharmacokinetics of an oral contraceptive containing ethinyl estradiol and norgestimate in healthy HIV-negative women. Antivir Ther. 2011;16(2): 149-156. CrossRef. Medline

8. Landolt NK, Phanuphak N, Ubolyam S, Pinyakorn S, Kerr S, Ahluwalia J. Significant decrease of ethinylestradiol with nevirapine, and of etonogestrel with efavirenz in HIV-positive women. J Acquir Immune Defic Syndr. 2014;66(2):e50-e52. CrossRef. Medline

9. Carten ML, Kiser JJ, Kwara A, Mawhinney S, Cu-Uvin S. Pharmacokinetic interactions between the hormonal emergency contraception, levonorgestrel (Plan B), and Efavirenz. Infect Dis Obstet Gynecol. 2012;2012:137192. CrossRef. Medline

10. Trussell J. Contraceptive efficacy. In: Hatcher RA, Trussell J, Nelson AL, Cates W, Kowal D, Policar M. Contraceptive technology: twentieth revised edition. New York: Ardent Media; 2011. Available from: http://www.contraceptivetechnology.org/ wp-content/uploads/2013/09/CTFailureTable.pdf

11. Patel RC, Onono M, Gandhi M, Blat C, Hagey J, Shade SB, et al. Pregnancy rates in HIV-positive women using contraceptives and efavirenz-based or nevirapine-based antiretroviral therapy in Kenya: a retrospective cohort study. Lancet HIV. 2015;2(11): e478-e482. CrossRef. Medline

12. Perry SH, Swamy P, Preidis GA, Mwanyumba A, Motsa N, Sarero HN. Implementing the Jadelle implant for women living with HIV in a resource-limited setting: concerns for drug interactions leading to unintended pregnancies. AIDS. 2014 28(5):791-793. CrossRef. Medline

13. Scarsi KK, Darin KM, Nakalema S, Back D, Byakika-Kibwika P, Else L, et al. Levonorgestrel implant + EFV-based ART: unintended pregnancies and associated PK data. Abstract No. 85LB. Presented at: Conference on Retrovirsuses and Opportunistic Infections (CROI); 2015 Feb 23-26; Seattle, Washington. Abstract available from: http://www. croiconference.org/sessions/levonorgestrel-implant-efv-basedart-unintended-pregnancies-and-associated-pk-data

14. Kreitchmann J, Innocente AP, Preussler GM. Safety and efficacy of contraceptive implants for HIV-infected women in Porto Alegre, Brazil. Int J Gynaecol Obstet. 2012;1 17(1):81-82. CrossRef. Medline

15. Pyra M, Heffron R, Mugo NR, Nanda K, Thomas KK, Celum C, et al. Partners in Prevention HSVHIV Transmission Study and Partners PrEP Study Team. Effectiveness of hormonal contraception in HIV-infected women using antiretroviral therapy. AIDS. 2015;29(17):2353-2359. CrossRef. Medline 
16. Mäkäräinen L, van Beek A, Tuomivaara L, Asplund B, Coelingh Bennink $H$. Ovarian function during the use of a single contraceptive implant: Implanon compared with Norplant. Fertil Steril. 1998;69(4):714-721. CrossRef. Medline

17. Croxatto HB, Mäkäräinen. The pharmacodynamics and efficacy of Implanon. An overview of the data. Contraception. 1998; 58(6 Suppl):91S-97S. CrossRef. Medline

18. World Health Organization (WHO). Medical eligibility criteria for contraceptive use. Fifth edition. Geneva: WHO; 2015. Available from: http://www.who.int/reproductivehealth/ publications/family_planning/MEC-5/en/

19. Cohn J, Bekker LG, Bygrave H, Calmy A. Hit me with your best shot: dolutegravir - a space in the next WHO guidelines? AIDS. 2015;29(16):2067-2070. CrossRef. Medline
20. Song IH, Borland J, Chen S, Wajima T, Peppercorn AF, Piscitelli SC. Dolutegravir has no effect on the pharmacokinetics of oral contraceptives with norgestimate and ethinyl estradiol. Ann Pharmacother. 2015;49(7):784-789. CrossRef. Medline

21. Barnhart M, Shelton J. ARVs: the next generation. Going boldly together to new frontiers of HIV treatment. Glob Health Sci Pract. 2015;3(1):1-11. CrossRef. Medline

22. Panel on Antiretroviral Guidelines for Adults and Adolescents. Guidelines for the use of antiretroviral agents in HIV-1-infected adults and adolescents. Washington (DC): Department of Health and Human Services; last updated 2015 Apr 8 [cited 2015 Nov 17]. Available from: http://www.aidsinfo.nih.gov/ ContentFiles/AdultandAdolescentGL.pdf

Cite this article as: Shelton JD. Reduced effectiveness of contraceptive implants for women taking the antiretroviral efavirenz (EFV): still good enough and for how long? Glob Health Sci Pract. 2015;3(4):528-531. http://dx.doi.org/10.9745/GHSP-D-15-00356.

(c) Shelton. This is an open-access article distributed under the terms of the Creative Commons Attribution License, which permits unrestricted use, distribution, and reproduction in any medium, provided the original author and source are properly cited. To view a copy of the license, visit http://creativecommons.org/licenses/by/3.0/. When linking to this article, please use the following permanent link: http://dx.doi.org/10.9745/GHSP-D-15-00356. 